\title{
Molecular epidemiology of HIV-1 in Rio Grande, RS, Brazil
}

\author{
Epidemiologia molecular do HIV-1 em Rio Grande, RS, Brasil \\ Ana Maria Barral de Martínezi,2, Edel Figueirêdo Barbosa ${ }^{2}$, Paulo César Pelegrino Ferreira $^{2}$, \\ Fabiola Adriene Cardoso' ${ }^{2}$, Jussara Silveira', Gabriela Sassi', Cláudio Moss da Silva', \\ Vera Mendonça-Signorini ${ }^{1}$ and Carlos Maurício de Figueiredo Antunes ${ }^{2,3}$
}

\begin{abstract}
We conducted a molecular epidemiological study to investigate HIV-1 strains in Rio Grande, southern Brazil, searching for an association with transmission mode and risk behavior. Patients (185) identified at an AIDS treatment reference Hospital, from 1994 to 1997, were included; from which 107 blood samples were obtained. Nested PCR was realized once for each sample; for amplified samples (69) HIV subtypes were classified using the heteroduplex mobility assay. Subtypes identified were B (75\%), C (22\%) and F (3\%). All infections with $C$ were diagnosed after 1994. Comparing patients with $B$ and $C$, no differences were detected regarding demographic, clinical and laboratory characteristics; survival analysis did not reveal differences in HIV to AIDS evolution. A higher proportion of injecting drug users, IDU (not significant, $p<.07$ ) was found among those with $C$. This suggests that $C$ may have been introduced in this area through IDU, and is being spread, probably by their sexual partners, to persons with other risk practices.
\end{abstract}

Key-words: Molecular epidemiology. HIV subtypes. Modes of transmission.

Resumo Um estudo de epidemiologia molecular foi conduzido para investigar subtipos de HIV-1 circulando em Rio Grande, RS, buscando uma associação com modos de transmissão e comportamentos de risco. Pacientes (185) identificados de 1994 a 1997, em um Hospital de referência para o tratamento da AIDS foram incluidos; amostras de sangue foram obtidas de 107. A reação em cadeia da polimerase (PCR) foi realizada uma única vez; nas amostras que amplificaram, (69) o subtipo foi classificado pelo ensaio de mobilidade do heteroduplex (HMA). Os subtipos de HIV identificados foram B (75\%), C (22\%) e F (3\%). As infecções com C foram diagnosticadas após 1994. Pacientes infectados com B e C não mostraram diferenças (características demográficas, clínicas e laboratoriais); a análise de sobrevida não mostrou diferenças na evolução HIV-AIDS. Maior proporção de usuários de drogas injetáveis (UDI) (não significativa, $p<0,07$ ), foi identificada entre infectados com C. Este resultado sugere $C$ ter sido introduzido nesta área através dos UDI, sendo transmitido pelos seus parceiros sexuais, a pessoas com outras práticas de risco.

Palavras-chaves: Epidemiologia molecular. Subtipos do HIV. Modos de transmissão.

Although Brazil ranks fourth in the world regarding the number of reported AIDS cases, information about the molecular diversity of circulating HIV-1 strains is still scarce for the Country as a whole ${ }^{4}{ }^{13}$. Up to date, four different subtypes (clades) have already been identified: $\mathrm{B}, \mathrm{C}, \mathrm{D}$ and $\mathrm{F}^{\mathrm{P}}$.

The evaluation of $\mathrm{C}_{2}-\mathrm{V}_{3}$ regions of the HIV-1 envgene obtained from different Brazilian geographical locations has furnished important information regarding the virus genetic diversity. The data were obtained by sequencing HIV-1 samples amplified by polymerase chain reaction
(PCR) directly from peripheral lymphocytes ${ }^{11}{ }^{13}$, from viral isolates ${ }^{3}$ and by the evaluation of DNA heteroduplex formation with standard strains (heteroduplex mobility assay, HMA ${ }^{15}$.

Until 1995, 91\% (180/199 samples) of identified HIV1 clades in Brazil ${ }^{13}$ were genetically related to the subtype B isolates described in the United States and Haiti; however, $40 \%$ of these isolates presented differences from the original B: instead of GPGR, the GWGR motif was found in the crown of $V_{3}$ loops, characterizing a Brazilian subtype B. Subtypes $F$ and $C$

\footnotetext{
1. Fundação Universidade Federal do Rio Grande, Rio Grande, RS; 2. Universidade Federal de Minas Gerais, Belo Horizonte, MG; 3. Santa Casa de Misericórdia, Belo Horizonte, MG.

Address to: Prof. Carlos Maurício de Figueiredo Antunes. Dept ${ }^{\circ}$ de Parasitologia/ICB/UFMG, Caixa Postal 486, 31270-901 Belo Horizonte, MG, Brasil. Tel: 5531 3499-2860.

E-mail:antunesc@mono.icb.ufmg.br

Recebido para publicação em 22/10/2001.
} 
comprised $9 \%$ of the samples ( 7 and $2 \%$, respectively). It is worth underscoring that $30 \%$ (3 out of 10 ) of samples isolated from the south of the Country were classified as subtype C. A single $B / F$ recombinant was also detected ${ }^{912}$.

More recent data have shown that approximately $14.9 \%$ of isolates from Rio de Janeiro belong to subtype $\mathrm{F}$; dual (F-B, F-D and B-D) and recombinant infections (all B-F) were also found. In Belém, State of Pará and Rio de Janeiro, subtype $D$ isolates were reported and in Manaus, State of Amazonas dual and recombinant infections (B-F) were acknowledged ${ }^{10} 14$.

Results from most of these investigations were based on samples obtained with objectives other than virus classification; no information describing participants was collected. Data pertaining to risk factors for HIV transmission and patients' demographic, clinical or laboratory characteristics were not obtained.

The city of Rio Grande is situated in the southeast of Rio Grande do Sul State, southern Brazil; the State has frontiers with Uruguay, Paraguay and Argentina. According to the 2000 Brazilian Census, it has a population of 186,755 inhabitants. It is an important port, fishing industry being its main economic activity. The Rio Grande do Sul State Health Department ranks Rio Grande as the third city in number of AIDS patients in the State: up to the end of 1997, 241 cases had already been reported to the Health Department. Currently
(September, 2000), the Ministry of Health has registered 386 cases of AIDS from Rio Grande.

The University Hospital "Dr Miguel Riet Corrêa Jr" (HU) from the "Fundação Universidade de Rio Grande" (FURG) is a reference center for HIV/AIDS diagnosis and treatment, covering the southern part of the Rio Grande do Sul State. The majority of patients diagnosed in this area are referred to the $\mathrm{HU}$ for follow-up and treatment.

The objective of the present investigation was to conduct a molecular epidemiological investigation of HIV-1 subtypes in patients identified at the HU in Rio Grande. Besides virus subtypes, information about patients epidemiological, clinical and laboratory characteristics were obtained, as an attempt to investigate possible associations between subtypes and (1) mode of transmission and (2) HIV/AIDS natural history. Rio Grande was chosen as an appropriate place to conduct this investigation according to its characteristics: (1) being a port, which suggests that a great diversity of HIV-1 subtypes could be identified due to an increased probability of several independent viral introductions into the area; (2) being close to three different countries, again suggesting an opportunity of increased viral subtype diversity; (3) reported higher prevalence of subtype $\mathrm{C}$, compared to the Brazilian data and (4) the existence of a reference Hospital for HIV-1/ AIDS patients follow-up and treatment.

\section{MATERIAL AND METHODS}

Patients. All patients with a serologically confirmed diagnosis of HIV-1 infection (ELISA and confirmatory Western-Blot) or AIDS, identified at the Infectious Diseases Clinic, HU/FURG, from August 1994 to October 1997 were included in the study. After signing an informed consent, they were interviewed for demographic, social and behavioral information. At interview time, a sample of 5.0 $\mathrm{ml}$ of blood in an anticoagulant was obtained from those who agreed to participating in the study. All participants had their medical records examined for clinical and laboratory data. Subsequent follow-up information about treatment, opportunistic infections, clinical evolution, hospitalization and death were obtained from their medical records or by interviewing the responsible physician. The AIDS definition from CDC was adopted².

Cells. Peripheral blood mononuclear cells (PBMC) were obtained using Ficoll-Hypaque (Pharmacia, Sweden) centrifuge gradient separation. The cells $\left(1 \times 10^{6}\right)$ were lysed in $200 \mu$ l of a buffer (TE, pH8.1; Triton-X 100, 0.001; SDS, $0.0001 \%$ ) and digested in $50 \mu \mathrm{g}$ of $\mathrm{K}$ proteinase in each tube, for one hour, at $56^{\circ} \mathrm{C}$. After digestion, $\mathrm{K}$ proteinase was inactivated at $95^{\circ} \mathrm{C}$ for 10 minutes.

Polymerase Chain Reaction. HIV-1 DNA was directly amplified from the PBMC lysate. The PCR was conducted according to World Health Organization (WHO) recommendations ${ }^{17}$. Only one attempt to amplify the viral DNA was done for each sample. Two amplification rounds were conducted: in a nested PCR protocol. The first reaction was done for a total volume of $20 \mu \mathrm{l}(50 \mathrm{mM} \mathrm{KCl}, 10 \mathrm{mM}$ tris- $\mathrm{HCl} \mathrm{pH} 8.3,1.25-1.8 \mathrm{~m}$ $\mathrm{MgCl}_{2}, 1 \% \mathrm{DMSO}, 1 \%$ glycerol, 5 pmol from each primer, $0.2 \mathrm{mM}$ of each dNTP and $2.5 \mathrm{U}$ of taq polymerase). As template, $2 \mu \mathrm{l}$ of PBMC lysate from each patient was added. The reactions were conducted under the following conditions: three initial cycles, at 94, 55 and $72^{\circ} \mathrm{C}$ for one minute; 32 subsequent cycles at $94^{\circ} \mathrm{C}$ for 15 seconds, $55^{\circ} \mathrm{C}$ for 45 seconds, $72^{\circ} \mathrm{C}$ for one minute, and a final extension at $72^{\circ} \mathrm{C}$ for five minutes. To amplify the internal fragments, in a total final volume of $100 \mu \mathrm{l}$, the same protocol was used with $2 \mu$ l of first round products as template. The reference subtypes (obtained from WHO) were amplified using internal primers (second round) and 10ng of plasmid as template ${ }^{5}$.

Primers. Primers ED3 and ED14 (bases 5956-5985 and 7960-7031 from HIV-1 HXB2, Genbank access $\mathrm{K} 03455)$ were used in the first amplification round. These sets of primers amplify a $2.0 \mathrm{~Kb}$ fragment. In the second round the following internal primers were used: ED5 and ED12, corresponding to bases $6556-6581$ and 78227792, amplifying an internal fragment of approximately $1.2 \mathrm{~Kb}$ in the $\mathrm{V} 1-\mathrm{V} 5$ region of gp120; ES7 and ES8, bases 7001-7020 and 7667-7647, amplifying a $0.7 \mathrm{~Kb}$ fragment in V3-V5 regions of gp120; ED31 and ED33, bases 68166844 and $7359-7380$, which amplify a $0.5 \mathrm{~Kb}$ fragment in the $\mathrm{C} 2-\mathrm{C} 4$ region of $\mathrm{gp} 120^{517}$. 
Heteroduplex mobility assay (HMA) ${ }^{5}$. For each patient, 5.0 $\mu$ l of nested PCR products (the fragment presenting the best resolution was chosen for subtyping) was mixed with 5.0 $\mu$ l of amplified DNA from standard HIV subtypes plus $1.0 \mu \mathrm{l}$ annealing buffer $10 x(1 \mathrm{M} \mathrm{NaCl}$ plus $0.1 \mathrm{M}$ Tris $\mathrm{pH} 7.8$ plus $0.02 \mathrm{M}$ EDTA) in $500 \mu \mathrm{l}$ eppendorf tubes. Control tubes contained the patients amplified products, final volume adjusted with water. Tubes were placed in PCR apparatus for a denaturation cycle ( $94^{\circ} \mathrm{C}$ for 2 minutes), being immediately placed in an iced bath afterwards.

HMA fractioning. The samples were then fractioned in a $5 \%$ non-denaturating polyacrylamide gel, obtained from stock preparation (30\% acrylamid, $0.8 \%$ bisacrilamide in TBE). Polymerization was achieved by adding $50 \mu \mathrm{g}$ of ammonium persulfate and $33 \mu \mathrm{l}$ of TEMED. Gels were prepared in $19.5 \times 16 \mathrm{~cm}$ glass plates, using $0.8 \mathrm{~mm}$ spacers. Electrophoresis was carried out in GIBCO BRL V15-V17 vertical model. Electrophoresis conditions varied according to amplified fragment length used in the heteroduplex: $1.2 \mathrm{~kb}, 200 \mathrm{~V}$ in six hours; $0.7 \mathrm{~Kb}, 250 \mathrm{~V}$ in three hours and $0.5 \mathrm{~Kb}, 250 \mathrm{~V}$ in two and half hours.

Polyacrylamide Gel Silver Staining. After electrophoresis, the gel was dyed by silver nitrate. Initial fixation was done with $40 \%$ methanol and $10 \%$ acetic acid in deionized water for 30 minutes, followed by $40 \%$ ethanol and $10 \%$ acetic acid for 15 minutes. Next, the gel was transferred to an oxidizing solution $(0.034 \mathrm{M}$ potassium bichromate plus 0.032 nitric acid), under agitation for 10 minutes. The gel was then repeatedly washed in deionized water until becoming transparent. Silver nitrate was added $(0.02 \%$ in deionized water) and the preparation kept in a dark room for 30 minutes. To visualize the electrophoretic bands, a solution with $2.97 \%$ of sodium carbonate plus $0.05 \%$ of paraformaldehyde in distilled water was added. The reaction was stopped by adding $10 \%$ acetic acid.

\section{RESULTS}

Study population. From August 1994 to October 1997, 185 patients were identified and included in the study. The male/female ratio was 2 to $1: 122(65.9 \%)$ male/ $63(34.1 \%)$ female patients. The mean age was $33.4 \pm 9.7$ years, (range 15 to 66 years). No statistically significant difference between mean age was found comparing males and females. The majority was white $(86 \%)$ and stable residents of Rio Grande in the last five years (90\%).

Regarding marital status, 71 (38.4\%) patients reported being married or having a stable relationship with a single partner for more than one year, 100 (54.1\%) informed being single or not having a stable relationship for more than one year and $12(6.5 \%)$ reported being widows; for two patients this information was not available.

In relation to educational history, $115(62 \%)$ had not completed elementary school and only 28 (15.1\%) reported having completed senior high school or college.

Homo or bisexual behavior were reported as the mode of HIV-1 infection by 45 (24\%) participants, whereas 96 $(52 \%)$ related heterosexual activities as the source of their infection. Among those, 27(28\%) had more than three sexual partners/year, while $20(21 \%)$ said to have been infected by their stable partner. The stable partner was reported as the source of infection by $36(57 \%)$ female participants. Injecting drug use (IDU) was responsible for $41(22 \%)$ infections. Male heterosexuals reported higher use of intravenous drugs when compared to other groups (statistically significant difference).

Clinical findings. At first medical visit, 126 (68.1\%) participants were classified as HIV infected and 55 (29.7\%) as AIDS patients; clinical classification was not found for four participants. According to CDC classification, 37 (67.3) were type $A, 4(7.3 \%)$ type $B$ and $14(25.4 \%)$ type $C$. The AIDS defining condition was $\mathrm{CD}_{4}<200 / \mathrm{mm}^{3}$, tuberculosis and pneumocystosis for 19 $(35 \%), 16(29 \%)$, and $8(14 \%)$ patients, respectively. In lower proportions, oral candidiasis, cerebral toxoplasmosis, cryptococcosis and cryptosporidiosis were also reported.

Sexually transmitted infections (STI) were diagnosed in $52(28 \%)$ patients, some presenting more than one diagnosis. Gonorrhea presented the highest frequency (30 patients), followed by syphilis and hepatitis B (13 and 10 , respectively). No difference regarding STI distribution was found comparing sex, risk behavior or HIV/AIDS clinical classification.

$\mathrm{CD}_{4}$ count was available for $169(91 \%)$ patients throughout the investigation. The mean count (first examination) for HIV infected was $381 \pm 205 / \mathrm{mm}^{3}$, whereas for AIDS patients was $130 \pm 119 / \mathrm{mm}^{3}$. Again, no difference in mean $\mathrm{CD}_{4}$ counts for both HIV infected and AIDS patients was detected, comparing sex, age and risk behavior.

HIV-1 subtypes. Blood samples were collected from a sub-sample of 107 participants who agreed to take part in the investigation. After a single amplification attempt, fragments from seven patients presented better resolution when amplified with internal primers ED5ED12, from 10 patients with ES7-ES8 primers and from 52 patients with ED31-ED33 primers. Samples from 38 patients did not amplify or presented weak amplifications and could not be used for HMA subtyping. From the total of 69 samples amplified, $52(75 \%)$ were identified as subtype B, $15(22 \%)$ as subtype C and $2(3 \%)$ as subtype $F$ (Table 1). It should be emphasized that all patients infected with HIV-1 subtype $\mathrm{C}$ were diagnosed after 1994. The comparison of characteristics between (1) participants included in the HMA sub-sample with those from the study population and (2) participants whose blood samples were amplified and used for HMA sub-typing with those not sub-typed (with regard to age, sex, race, marital status, education, risk factors for HIV 
infection, both sexual behavior and IDU, history of STI, HIV infection or AIDS in the first clinical visit, CDC HIV/ AIDS classification and CD4 count), did not reveal any significant difference.

Comparison of Participants with HIV-1 B or C subtype Infection. The results obtained contrasting characteristics of participants classified as infected with subtypes B or $\mathrm{C}$ can be seen in Table 2; due to the small frequency observed, participants classified as subtype $F$ were removed from further analysis. For most of the studied variables, no significant differences were found; opportunistic infections included viral (CMV and Herpes), bacterial (tuberculosis bacilli), fungal ( $P$. carinii) and parasitic (T. gondii) agents. However, a higher proportion of IDU was reported by HIV-1 C patients (46.7\%) when compared to HIV-1 B (23.1\%), in the limit of statistical significance.

Table 1 - HIV-1 subtypes identified in Rio Grande RS, Brazil, 1994/97.

\begin{tabular}{lrrrr}
\hline Primers & \multicolumn{2}{c}{ Samples } & \multicolumn{3}{c}{ Subtypes } \\
\cline { 3 - 5 } & & $\mathrm{B}$ & $\mathrm{C}$ & $\mathrm{F}$ \\
\hline ED5/E12 & 7 & 5 & 2 & - \\
ES7/ES8 & 10 & 9 & 1 & - \\
ED31/ED33 & 52 & 38 & 12 & 2 \\
\hline Total & 69 & 52 & 15 & 2 \\
\hline$\%$ & - & 75 & 22 & 3
\end{tabular}

Table 2 - Comparison of averages and proportions of selected variables between patients infected with HIV-1 B and C subtypes, Rio Grande - RS, Brazil, 1994/97.

\begin{tabular}{|c|c|c|c|c|c|}
\hline \multirow[b]{3}{*}{ Variable $^{1}$} & \multicolumn{5}{|c|}{ HIV-1 Subtypes } \\
\hline & \multicolumn{2}{|l|}{ B } & \multicolumn{2}{|l|}{$\mathrm{C}$} & \multirow[b]{2}{*}{ Test $^{2}$} \\
\hline & number & $\%$ & number & $\%$ & \\
\hline \multicolumn{6}{|l|}{ Gender } \\
\hline male & 38 & 73.1 & 11 & 73.3 & NS \\
\hline female & 14 & 26.9 & 4 & 26.7 & - \\
\hline \multicolumn{6}{|l|}{ Race } \\
\hline white & 48 & 94.1 & 14 & 93.3 & NS \\
\hline \multicolumn{6}{|l|}{ Marital status } \\
\hline married & 16 & 32.0 & 7 & 46.7 & NS \\
\hline single & 33 & 62.0 & 8 & 53.3 & - \\
\hline widow & 1 & 2.0 & 0 & - & - \\
\hline \multicolumn{6}{|l|}{ Clinical status } \\
\hline HIV-1+ & 30 & 58.8 & 11 & 73.3 & NS \\
\hline AIDS & 21 & 41.2 & 4 & 26.7 & - \\
\hline Positive STI & 14 & 26.9 & 4 & 36.4 & NS \\
\hline Opportunistic infections & 40 & 76.9 & 10 & 66.7 & NS \\
\hline \multicolumn{6}{|l|}{ Sexual risk behavior } \\
\hline homo/bisexual & 13 & 26.0 & 3 & 20.0 & NS \\
\hline heterosexual & 36 & 72.0 & 12 & 80.0 & - \\
\hline IDU & 12 & 23.1 & 7 & 46.7 & $P<0.07$ \\
\hline
\end{tabular}

Clinical and laboratory parameters of HIV disease progression $\left(\mathrm{CD}_{4} 200\right.$ or $\left.>200 \mathrm{~mm}^{3}\right)$ from date of diagnosis to the last medical visit, were compared by survival analysis (Kaplan-Meyer) between individuals infected by HIV-1 B or C. No significant differences were detected (log-rank test, data not shown).

\section{DISCUSSION}

The results obtained in this investigation strongly suggest the HIV-1/AIDS epidemic observed in Rio Grande RS, to be similar to the Brazilian epidemic ${ }^{616}$ as a whole: (1) a marked increase in heterosexual transmission (49.0\% in this study) was detected in the 90 's, not followed by a decrease in infection in homo/ bisexuals or IDU (24.0 and $22.7 \%$ respectively); (2) the epidemic reaching smaller cities outside the southeast region and (3) the epidemic reaching lower socioeconomic segments of the population (in this investigation estimated by years of education).

Reported (to the Brazilian Ministry of Health) HIV/ AIDS patients are offered, when necessary, free treatment through a network of reference Clinics and Hospitals all over the Country, HU/FURG being the reference Hospitals for the southern part of Rio Grande 
do Sul State. As a consequence, one can be confident that all HIV/AIDS patients (or, at least, the majority) from this area, during the study period, were identified and included in the investigation. HIV subtype classification was conducted using specimens, which amplified after a single attempt, from a sub-sample of the study population. Because no differences were detected between those patients included and not included (refusals) for subtyping and those patients whose samples amplified and did not amplify, the results obtained should reflect the actual virus occurrence in this part of the Country. It can be argued that those samples not amplifying after the first attempt could represent more divergent strains; however, up to now, no reports of different subtypes in this region of Brazil have been published.

Previous reports of HIV subtypes distribution in Brazil were also confirmed by this study. The city of Rio Grande, being an important port (similar to Rio de Janeiro and Belém) and being located near the border of three countries was, as assumed, an appropriate place to conduct this type of investigation due to high probability of having had new HIV strains introduced. The initial reports of a higher proportion of HIV-1 C subtypes in the state of Rio Grande do Sul were confirmed by this investigation.

Regarding clinical progression and epidemiological characteristics, no significant differences were found in this study, when individuals infected with subtype B were compared to those harboring subtype $\mathrm{C}$. Comparisons of demographic (age, sex, race, marital status) or clinical data (HIV infection or AIDS, $\mathrm{CD}_{4}$ count, opportunistic infections, STIs), risk behavior (either sexual practices or injected drug use) and pathogenicity (HIV disease progression and decrease in $\mathrm{CD}_{4}$ count) related variables did not reveal any meaningful differences. However, no information regarding patients survival after AIDS diagnosis was obtained.
Reports of $\mathrm{C}$ subtype identification in the region began to appear from 1994 onward, suggesting a possible later introduction of this viral type, when compared to subtype B. Moreover, the higher proportion of this subtype identified among IDU, together with a higher rate of IDU among heterosexuals males, a high frequency of sexual promiscuity in this population subgroup ( $28 \%$ of heterosexuals reporting more than three partners/year) plus the large proportion of females $(57 \%)$ sexually infected by their stable partners add to this belief. It can be hypothesized that subtype $C$ was introduced in this region later than the subtype B, firstly among heterosexual male IDU, reaching the general population through their female sexual partners later on. However, nucleotide sequencing of viral genome and phylogenetic analysis must be carried out in order to prove this hypothesis.

Although no association between subtypes and HIV mode of transmission or AIDS natural history was detected in this investigation, several important questions regarding HIV subtypes remain unanswered and need further investigation. Among them, possible clades differential resistance to treatment and the necessity of developing clade-specific vaccines, should be considered as important research priorities. As already cited, the Brazilian Ministry of Health through its AIDS Control Program is offering free treatment (including protease inhibitors) to AIDS patients who fulfill specific conditions ${ }^{8}$; this program requires close monitoring of possible HIV drug-resistance, including subtype identification. Regarding HIV vaccines, recent reports suggest that those under field testing (USA, Thailand and Uganda) may not equally protect against different HIV clades. As phase II/III vaccine trials are planned to be initiated soon in Brazil, information on HIV subtype distribution will be essential in appraising vaccine efficacy.

\section{ACKNOWLEDGMENTS}

This work received support from Conselho Nacional de Desenvolvimento Científico e Tecnolólogico (CNPq), from Pro-Reitoria de Pesquisa da Universidade Federal de Minas Gerais (PRPq-UFMG), from Fundação de Amparo a Pesquisas do Estado de Minas Gerais (FAPEMIG) and from Fundação de Amparo a Pesquisas do Estado de Rio Grande do Sul (FAPERGS).

\section{REFERENCES}

1. Bastos FI, Szwarcwald CL. AIDS e pauperização: principais conceitos e evidências empíricas. Cadernos de Saúde Pública 16(supl 1)65-76. 2000.

2. Center for Diseases Control and Prevention. Revised classification for HIV infection and expanded surveillance case definition for AIDS among adolescents and adults. Morbidity and Mortality Weekly Report 41:(RR17)1-19, 1993.

3. Couto-Ferrnandez J, Janssens W, Heyndrikx L, Motte J, Fransen K, Peeters M, Delaporte E, Galvão-Castro B, Piot P, Van Der Groen G. Genetic and Antigenic Variavility of HIV Type 1 in Brazil. AIDS Research and Human Retroviruses 10: 1157-1163, 1994.
4. Couto-Fernandez J, Morgado M, Santos J,.Galvão-Castro B. 1992. Molecular and biological diversity of HIV-1 in Brazil. Memórias do Instituto Oswaldo Cruz 87: 249-255, 1992

5. Delwart E, Shpaer E, Mccutchain F, Louwagie J, Grez M, Rubsamen-Waigmann $\mathrm{H}$, Mullins J.Genetic relationships determined by a DNA heteroduplex mobility assay: analysis of HIV-1 env gene. Science 262: 1257-1261, 1993.

6. Fonseca MG, Bastos FI, Derrico M, Andrade CLT, Travassos C, Szwarcwald CL. AIDS e grau de escolaridade no Brasil: evolução temporal de 1986 a 1996. Cadernos de Saúde Pública 16(supl 1)77-87, 2000. 
7. HIV/AIDS/STD Epi Fact Sheet. Brazil, 1997. Monitoring the AIDS Pandemic Symposium. Rio de Janeiro-Brazil, November 4-5, 1997.

8. Ministério Saúde. Infecção pelo HIV em adultos e adolescentes. Recomendações para terapia anti-retroviral, Brasília, 1999.

9. Morgado M. Pontuações sobre a Rede Nacional de Isolamento e Caracterizacão do HIV no Brasil. Programa Nacional de Doenças Sexualmente Transmissíveis e AIDS. Secretaria de Assistência à Saúde. Ministério da Saúde. Cadernos Técnicos. p. 10-15, 1994b.

10. Morgado MG, Guimarães ML, Gripp CBJ, Costa Cl, Neves Jr I, Veloso VG, Linhares- Carvalho MI, Castelo-Branco LR, Bastos FI, Kuiken C, Castilho EA, Galvão-Castro B, Bongertz V, Evandro Chagas Hospital AIDS Clinical Research Group. Molecular Epidemiology of HIV-1 in Brazil: high prevalence of HIV-1 subtype $B$ and identification of an HIV-1 subtype $D$ infection in the city of Rio de Janeiro, Brazil. Journal of Acquired Immune Deficiency Syndrome and Human Retrovirology 18:488-494, 1998.

11. Morgado M, Sabino E, Bongertz V, Brigido L, Galvão-Castro B, Hendry M, Mayer A. V3 sequence diversity among Brazilian HIV1 samples. IX International Conference on AIDS, Berlin, Germany, 1993.

12. Morgado M, Sabino E, Shpaer E, Bongertz V, Brigido L, Guimaraes M, Castilho E, Galvão-Castro B, Mullins J, Hendry M, Mayer A.
Region Polymorphisms in HIV-1 from Brazil: prevalence of Subtype B Strains Divergent from North American/European Prototype and detection of Subtype F. AIDS Research and Human Retroviruses 10: 569-576, 1994.

13. Potts K, Kalish M, Lott T, Orloff G, Luo CH, Bernard M, Brites Alves C, Badaro R, Suleiman J, Ferreira O, Schochetman G, Johnson Jr W, Ou Ch, Ho J, Brazilian Collaborative AIDS Research Group. Genetic heterogeneity of the $\mathrm{V} 3$ region of the HIV-1 envelope glycoprotein in Brazil. AIDS 7: 1191-1197, 1993.

14. Ramos A, Tanuri A, Schechter M, Rayfield MA, Hu DJ, Cabral MC, Bandea Cl, Baggs J, Pieniazek D. Dual and Recombinant Infections: An Integral Part of the HIV-1 Epidemic in Brazil. Emerging Infectious Diseases 5:65-74, 1999.

15. Sabino E, Shpaer E, Morgado M, Korber B, Diaz R, Bongertz V, Cavalcante S, Galvão-Castro B, Mullins J, Mayer A. Identification of Human Immunodeficiency Virus Type 1 Envelope Genes Recombinant between Subtypes $B$ and $F$ in Two Epidemiologically Linked Individuals from Brazil. Journal of Virology 68: 6340-6346. 1994.

16. Szwarcwald CL, Bastos FI, Esteves MAP, Andrade CLT. A disseminação da epidemia da AIDS no Brasil, no período de 1987-1996: uma análise espacial. Cadernos de Saúde Pública 16(sup 1)7-19, 2000.

17. World Heath Organization, 1995. Guidelines for HIV Standard Isolation Procedures, Geneve, 1995. 